\title{
THE ROLES OF THE SUPREME COURT OF THE REPUBLIC OF INDONESIA IN ENFORCEMENT OF INTERNATIONAL ARBITRAL AWARDS IN INDONESIA
}

\author{
Mutiara Hikmah ${ }^{*}$ )
}

\begin{abstract}
Indonesia has been being a member of the 1958 New York Convention since 1981, namely upon issuance of the Presidential Decree No. 34 of 1981. Prior to taking into force of the Regulation of the Supreme Court of the Republic of Indonesia No. 1 of 1990 on Procedures for Enforcement of Foreign Arbitral awards, there were still constraints for the foreign business players in term of enforcement of arbitral awards in Indonesia. The Supreme Court as the highest judicial institution in Indonesia holds that international arbitral awards can not be enforced in Indonesia. After the Indonesian Supreme Court has issued such a regulation, enforcement of international arbitral awards in Indonesia began to be enforceable, because the procedural law that governs the procedures for execution of arbitral awards has been clear. In order to regulate better the international arbitral award problems in the hierarchy of legislation, on October 12, 1999, the Law on Arbitration and Alternative Dispute Resolution was promulgated. In that Law, there is a special part discussing the International Arbitration. This study examines the development of international arbitral award enforcement in Indonesia before Indonesia becoming member of the 1958 New York Convention, until nowadays, by analyzing the international arbitral awards that were decided by the Supreme Court of the Republic of Indonesia after the coming into effect of the Arbitration Law.
\end{abstract}

Keywords: arbitral awards, international arbitration, supreme court

\section{Introduction}

\section{A. Enforcement of International Arbitral awards Before Taking Into Force of the Arbitration Law}

If studying the history of development of the international arbitral award enforcement in Indonesia, it can be mentioned that before Indonesia becoming member state of the 1958 New York Convention, the Supreme Court held that international arbitral awards in Indonesia can not be enforced. ${ }^{2}$

After Indonesia has became a member of the 1958 New York Convention through Presidential Decree No. 34 of 1981 dated August 5, 1981, international arbitral wards in Indonesia have not yet enforceable. Although most of experts and legal practitioners argue that the convention is selfexecuting ${ }^{3}$ in nature, but the Indonesian Supreme Court had a different stance.

${ }^{1 *}$ Lecturer in the Faculty of Law UI for Course Subject group of International Civil Law and Law and Human Rights in the Faculty of Economics UI for Indonesian Business Law Course Subject, and researcher in the Human Rights Study Institute in the Faculty of Law UI.

${ }^{2}$ In this case, there is different of opinion between the Chief Justice of the Supreme Court of the Republic of Indonesia and the Academics/legal practitioners, concerning passive stelsel and active stelsel

${ }^{3}$ No more implementing regulation issued by the Government of Indonesia is required, because 
The Indonesian Supreme Court as the highest judicial body held that it still requires an Implementing Regulation of the Presidential Decree No. 34 of 1981, given such a Presidential Decree contains participation of the Indonesia State with the 1958 New York Convention, together with two requirements that are obeyed by the Republic of Indonesia. Such Presidential Decree does not provide further on which court is competent to examine and give order of execution of the international arbitral awards in Indonesia.

Concerning the Stance of the Indonesian Supreme Court, there are four types of Supreme Court awards that contain international arbitration clause, on which the parties have previously made agreement, but disputes of pactum de compromettendo ${ }^{4}$ has arose. These four types of award are: ${ }^{5}$

a. there is an international arbitration clause, but the defendant did not submit an exception on absolute competence and chose to keep silent; ${ }^{6}$

b. there is an international arbitration clause, submit as an exception on absolute competence by the defendant; ${ }^{7}$

c. there is an international arbitration clause recognized by both parties, but the parties disputed on which arbitration body is competent; 8

$\mathrm{d}$. there is an international arbitration clause, but, in addition, there is also an agreement on the court competence. ${ }^{9}$

Inconsistency of judiciary bodies in Indonesia is not only in the choice of arbitration forum, but also in term of international arbitral award enforcement.

the convention itself states that the method of enforcement of arbitral award pronounced abroad is the same as those that is applicable to the domestic arbitration awards of the convention members. See: Sudargo Gautama (b), op.cit., page 2.

${ }^{4}$ Free translation of Article 615 (3) RV, namely: The parties are allowed to agree upon arbitration on any dispute that may arise in the future. See: Tineke L.T. Longdong, op.cit, page 195.

${ }^{5}$ ibid.

${ }^{6}$ Can be seen in the Award of the Supreme Court of the Republic of Indonesia No. 225 K/Sip/1976, 30-09-1983 jo. Award of Jakarta High Court No. 145/1973 PT/Perdata, 10-07-1975 jo. Central Jakarta District Court No. 310/1972 G, 21-03-1973 in the case between Dato Wong Hech Guong cs vs. Pangemanan, has decided the claim for default. See: Sudargo Gautama (k), Himpunan Jurisprudensi Indonesia Yang Penting Untuk Praktek Sehari-hari (Landmark Decision) Together with the Comments, volume 4 (Bandung: PT Citra Aditya Bakti, 1992), pages 49-74.

${ }^{7}$ Can be seen in the award of the Supreme Court of the Republic of Indonesia No. 2924 K/Sip/1981, 22-02-1982 jo. Award of the Jakarta High Court No. 57/1981/PT Perdata, 07-05-1981 jo. North Jakarta District Court No. 113/1980 G, 18-12-1980 in the case of Ahju Forestry Company Limited vs. Sutomo. See: Sudargo Gautama, ibid., pages 1-48. Can also be seen in the award of the Supreme Court of the Republic of Indonesia No. 3409 K/Pdt/1986, 31-10-1987 jo. Jakarta High Court No. 312/Pdt/1986/PT DKI, 21 07-1986 jo. Central Jakarta District Court No. 697/Pdt.G/1984/PN.Pdt, 14-08-1985 in the case between the Governor KDKI Jakarta cs vs. Drc. Investment LTD. See: Setiawan, Analisa dan Evaluasi Perkembangan Yurisprudensi di Bidang Hukum Kontrak Internasional Sejak tahun 1945, Pusat Perencanaan Pembangunan Hukum Nasional, BPHN Year 1990/1991, pages 1-13.

${ }^{8}$ Can be seen in the award of the Supreme Court No. 3992 K/Pdt/1985, 04-05-1988, jo. Jakarta High Court No. 270/Pdt/1985/PT DKI, 31-06-1985 jo. Central Jakarta District Court No. 301/Pdt.G/1984 15-11-1984, in the case of PT Batu Mulia Utama vs. SSC (Sainrapt Et Brite Societe Auxiliarie D’Enterprises Societe Routine Colas). See: Himpunan Putusan Mahkamah Agung tentang Arbitrase, Proyek Yurisprudensi Mahkamah Agung RI, 1989, on pages 74-81. Award analysis can be seen in: Tineke T.L. Longdong, op.cit., page 208.

${ }^{9}$ Can be seen in the award of the Supreme Court No. 1458 K/Pdt/1992, 30-03-1994 jo. Surabaya High Court No. 769/Pdt/1990/PT Sby, 1-10-1991 jo. Surabaya District Court No. 568/Pdt/G/1989/PN Sby, 21-07-1990, in the case of Bank Deutsche Genossenschaft vs. PT Lumbung Tani Indonesia cs. See: Varia Peradilan, "Kasus Wan Prestasi, Loan Agreement, Peran Arbitrase”, Majalah Hukum Year X, No. 110 November 1994, pages 94-118. Award analysis can be seen in: Tineke L.T. Longdong, op.cit., page 210. 
If discussing the arbitral award enforcement in Indonesia, the discussion will begin from the time of entry into force of the Geneva Conventions of 1927 for Indonesia, as former Dutch colony. This period is the early history of periodization of regulation on international arbitral award enforcement in Indonesia.

\section{B. Term of validity of the Staatsblad 1933 No. 131 on ratification of the 1927 Geneva Convention by the Dutch East India Government}

With the declaration of independence of the Republic of Indonesia on August 17, 1945, a succession of state has occurred. The Government of the Republic of Indonesia considers that the Declaration of Independence August 17, 1945 is legal, thus the only sovereign one in the Dutch East India territory is the strong base (juridically as a fundament) to create a new legal order of the Republic of Indonesia, and subvert the Dutch colonial legal order. The State of the Republic of Indonesia is sovereign both internally and externally. ${ }^{10}$

In relation to the birth of new state of the Republic of Indonesia as the successor state, it needs to understand the position of international treaties that were entered into by the Dutch Government and also declared as applicable to the Dutch East India territory, and attitudes of Indonesia towards such agreements. To study the position of these agreements, taken as the starting point is when the Round Table Conference (KMB) was legalized by Indonesia. Due to physical revolution period, within that period the Government of Indonesia has not fully paid attention to the normal international relation. ${ }^{11}$

Starting at the Van Royen-Roem Statement, a Round Table Conference was held in Den Haag on August 23 up to November 2, 1949. At the same time a Draft Constitution of RIS was prepared by the Representatives of the Republic of Indonesia and the BFO. On December 27, 1949 Queen Juliana signed the Deed of Delivery of Sovereignty. Thus, from that time, all results of the Round Table Conference and the Constitution RIS were applicable, and the Netherlands Indonesian Union was born.

With existence of the Round Table Conference agreement, the Dutch formally recognized Indonesia's sovereignty on the entire former territory of the Dutch East India with deferment of settlement of West Irian territory. As a complement to the Round Table Conference, a transitional agreement was also made. In the Article 5 of the agreement provides for the position of international treaties that were made by the Dutch government and also bind upon the former colonial territory of the Dutch East India. The Article 5 of the transitional agreement provides for position of international treaties that were made by the Dutch government in conjunction with United States of the Republic of Indonesia. That article reads as follows:

1. The United Republic of Indonesia and the Kingdom of the Netherlands interpreted that by paying attention to the second paragraph, all rights and obligations of the Kingdom due to the treaties and other international treaties that were entered into by the Kingdom, that they can be considered as the rights and obligations of the United Republic of Indonesia.

${ }^{10}$ Hasan Zaini, in Budi Lazarusli, SH \& Syahmin AK, SH, State Succession in Relation to International Agreements, Suksesi Negara Dalam Hubungannya dengan Perjanjian Internasional, (Bandung: Remadja Rosdakarya CV, 1986), page 84.

11 ibid. 
2. Without prejudice to the powers of the United Republic of Indonesia, it will announce termination of the treaties and agreements as referred to in the first paragraph or terminate their applicability to their jurisdiction otherwise in accordance with the provisions of the treaties and agreements, then, the first paragraph shall not apply to the treaties and agreements on them after being negotiated further by the by the United Republic of Indonesia and the Kingdom of the Netherlands, it will be concluded that the first paragraph shall not apply to the treaties and agreements.

The provisions in Article 5 of the transitional agreement above was to show, that the international treaties do not directly bind upon the former colonies that newly obtain their independence. For enforcement of international treaties in the newly independent countries, requires a further confirmation by their respective governments. The aforesaid provisions can impress that all international treaties are directly binding upon the government of the United Republic of Indonesia until ceased to apply.

Lemaire was in the opinion, that the transitional provisions must be interpreted in addition to the agreement between Indonesia and the Netherlands that bind only upon the parties, by referring to paragraph (1) of Article 5, also constitutes a unilateral statement of Indonesia to the third countries concerning the readiness to be bound of Indonesia to the international treaties. From this opinion, it can be concluded that Lemaire tended to assume continual bounded of Indonesia to the international treaties. As an evidence, Lemaire showed in Article 21, paragraph (7) of the Round Table Conference Agreement on Economy and Finance, where it was said that the trade and financial agreements that that effect at the time of the transfer of sovereignty on Indonesia will be accepted to be approval of the United Government of Indonesia and implemented by the government of Indonesia. In the annex to the agreement lists the number of trade and financial agreements. ${ }^{12}$

On contrary, another author, namely de Muralt who in his dissertation also discussed on the transitional article in the framework of the Round Table Conference Agreement, said that pressure ofinterpretation should not be puton the international treaties themselves, but on the rights and obligations arising from these treaties. Not all international treaties are applicable to Indonesia, as can be seen in existence of the rebus sic stantibus clause in paragraph (2) of Article 5, the content of the treaties themselves must be examined as if there is a clause which refers to the partial validity of agreement in Amsterdam, then it can not be applied outside Europe. ${ }^{13}$

As an effort of understanding better the attitude of the Government of Indonesia toward the international treaties made by the Dutch government, presented below is Captain Westerling case, so as to understand the position of international treaties after termination of the Round Table Conference.

When the Dutch colonial government and several countries in the world entered into treaties on extradition and these treaties were declared applicable to the Dutch East India. These countries Spain, Belgium, CongoBelgium and Ruanda regions - Urundi, Denmark, Liberia, Portugal, Italy, the Kingdom of Germany, the Republic of France, the Great Britain and

${ }^{12}$ W.L.G. Lemaire, Het Recht in Indonesie, (Bandung: Gravenhage, 1952), page 211. In Budi Lazarusli, ibid., page. 86 .

13 ibid., page. 87 
some regions as mandated by Swiss, United States, Mexico, Czechoslovakia, Finland, and Ireland. After the Proclamation of Indonesian Independence on August 17, 1945, these extradition treaties do not by themselves apply to the Republic of Indonesia. In that regard, Indonesia has experienced difficulty when requested for extradition to the British government to arrest Captain Westerling in Singapore in order to be surrendered to Indonesia. As known, Singapore at that time was still a British colonial. Captain Raymond Paul Pierre Westerling, after having committed in a series of killings of people in Bandung and Makassar (presently Ujung Pandang) in February 1950 and then escaped to Singapore. The colonial government in Singapore refused to surrender Westerling to Indonesia for reason of absence of extradition agreement between the United Kingdom and Indonesia.

The Captain Westerling extradition case is interesting to study about the application of Article 5 of the Transitional Regulation of the Round Table Conference. Captain Raymond Paul Pierre Westerling, in the Indonesian nation's eyes is a criminal who fled to Singapore which at that time was still a part of colony of the United Kingdom. In February 1950 the Government of Indonesia requested the British government to extradite captain Westerling to Indonesia based on the extradition agreement between the United Kingdom and the Netherlands, dated September 26, 1898.

Based on such a rebus sic stantibus principle ${ }^{14}$, the Government of Indonesia had no other choices but to annul the Round Table Conference agreement. Thus, based on Law Number 13 of 1956 (Statute Book: No. $27 / 1956)$ the Government of the Republic of Indonesia declared no longer bounded by the United Netherlands Indonesia and unilaterally terminated entirely the Round Table Conference agreement.

The reasons of the Government to annul the Round Table Conference agreement are as follows:

"... Thus, in a situation that has changed so mush and highly urgent to annul the Round Table Conference agreement for the National interest, the Government has no other choice than to annul the agreement on the basis of "rebus sic stantibus" that is applicable in the international law. According to the principle of rebus sic stantibus which means based on reality of existence of vital changes in home country of either party to the agreement, then such a party is entitled to withdraw from the agreement. On other words, in such a situation, the rebus sic principle on the Stantibus can be made as a basis to negate the principle of "pacta sunt servanda".15

The aforesaid quote from Government policy is considered necessary to measure the political relation between the Netherlands and Indonesia, which affect the Indonesia's attitude toward the international treaties made by the Dutch treated in the Dutch East India Colonial. Practice and attitude of Indonesia toward the agreements with respect to the state succession after the Law Number 13 of 1956 took effect, it can be known from the answer to the letter of Secretary General of the United Nations acting as Depositary Agency of International Agreements listed in the League of Nations in the

${ }^{14}$ Rebus sic stantibus principle means: the requirement that an agreement (inter states treaty) shall only remain valid, if the circumstances remains the same. See: S. Adiwinata, op.cit., page 22.

${ }^{15}$ Pacta sunt servanda principle means: agreements (similarly in inter-country law) must be complied with or adhered to. See: S. Adiwinata, op.cit., page 72. 
Reply dated February 16, 1959 Indonesia confirmed to remains be bound to the Geneva Convention (bold print made by the researcher). Thus, the foreign arbitral awards issues in Indonesia relate to the provisions in the Geneva Conventions. ${ }^{16}$

Based on Law No. 14 of 1970 on the main provisions of the judicial power, principally any dispute can be filed and examined and prosecuted by a court body that are conducted by the state, even Article 6 (1) of the Law provides that no one can be forced to waiver his/her rights to file his/her case before the court that is determined to him/her by law. Therefore, the Law No. 14 of 1970 itself does not contain an provision on possible arbitration at the will of the parties.

Regarding the applicability of the 1927 Geneva Convention, the convention is a refinement of the 1923 Geneva Protocol. ${ }^{17}$ The 1923 Geneva Protocol was made with two purposes, the first is to try to make an arbitration agreement in the form of an arbitration clause that is enforceable under the international law, and the second is to try to ensure that the arbitral award made according to an arbitration agreement can be enforced in within the territory of the country where the award is made.

In other words, the 1923 Geneva Protocol was purposed to ensure that the protocol participating countries support the international trade arbitration at the beginning and end of the arbitration process. At the beginning of arbitration process, the participating countries can ensure that the parties have decided their disputes to be decided through arbitration proceeding rather than in the court, and at the end of arbitration process they can ensure that the recognition and enforcement of their arbitral award can be enforced in their respective countries. ${ }^{18}$

The Geneva Protocol contains some limitations, both in terms of scope and effect of law, because it only applies to arbitration agreements that were made between the parties who respect the differences of jurisdiction of the participating countries. In addition, the Geneva Protocol applies only to countries that have conducted "commercial reservation". The Geneva Protocol does not provide for execution of international arbitration. However, with all of its limitations, the 1923 Geneva Protocol was the initial step toward the recognition and implementation of international arbitral treaties and awards. ${ }^{19}$

On September 26, 1927 with assistance of the League of Nations, the 1927 Geneva Convention was born. Purpose of this convention is to set on recognition and enforcement of arbitral awards in the convention participating states according to the arbitration agreement as set forth in the

${ }^{16}$ In viewing of the need for arbitration regulations that govern the international trade traffic, on April 28, 1933 the Dutch East India Government announced the Staatsblad 1933 No. 131 that became legal basis for the government participation in the 1927 Geneva Convention (that was signed on September 26, 1927), legalized in the initiative of the League of Nations, namely the Geneva Convention on the Execution of Foreign Arbitral Awards of 1927.

${ }^{17}$ Most of member countries of the 1923 Geneva Protocol are European countries, such as, Czechoslovakia, Denmark, Finland, France, Germany, Greece, Ireland, Norway, Poland, Portugal, Spain and the United Kingdom. One country is from Latin America, namely Brazil. And other Participating countries are India, Japan, New Zaeland and Thailand. See Alan Redfern \& Martin Hunter, op.cit., page 342.

${ }^{18}$ ibid., page. 341 .

${ }^{19}$ ibid., page. 342 . 
1923 Geneva Protocol. ${ }^{20}$ However, different from the Geneva Protocol which provides only the enforcement of arbitral awards in the countries where the awards are made, the Geneva Convention further governs the recognition and enforcement of arbitral awards in the convention participating countries, with three requirements, such as: ${ }^{21}$

i) The award shall be made based on the arbitration agreement in accordance with the 1923 Geneva Protocol;

ii) The award shall be made in one of the convention participating countries;

iii) The participants in the arbitration agreement shall be the legal subjects who have the authority in one of the participating countries.

According to Article 1 paragraph (2) point (d) of the 1927 Geneva Conventions, an arbitral award is final in the country where the award is made. ${ }^{22}$ However, in practice, such a provision gave rise to difficulties. In addition to necessity of obtaining exequatur from the enforcing country, such an arbitral award must also obtain exequatur from the state where the award is made certifying that such an award is final. ${ }^{23}$ By some writers this condition is also called as "double exequatur". ${ }^{24}$

Another provision that gave rise to difficulty in the practice, is Article 1, paragraph (2) point (e) of the 1927 Geneva Convention. That article requires that an arbitration award hall not contrary to the legal principles of the enforcing country. ${ }^{25}$ Notwithstanding some provisions which gave rise to difficulties in practice, this is the 1927 Geneva Convention which is the earliest history of implementing regulations of the international arbitration awards in Indonesia.

Although during the validity period of the Staatsblad 1933 No. 131 there were no cases relating to the enforcement of international arbitral awards in Indonesia, ${ }^{26}$ but as to the implementation of the 1927 Geneva

${ }^{20}$ With the birth of the 1927 Geneva Convention, not all members of the Geneva Protocol became its participants. Some countries that withdraw from membership were Brazil, Norway and Poland. However there were some countries that joined to be participating members of the 1927 Geneva Convention, such as, Burma, Kenya and Zambia. ibid., P 343.

${ }^{21}$ ibid., page. 342.

${ }^{22}$ That article reads: "To obtain such recognition or enforcement, it shall, further, be necessary (d) that the award has become final in the country in which it has been made, in the sense that it will not be considered as such if it is open to opposition, appeal or pourvoi en cassation (in the countries where such forms of procedure exist) or if it is proved the proceedings for that any proceedings for the purpose of contesting the validity of the award are pending."

${ }^{23}$ Alan Redfern, op.cit., page. 343.

${ }^{24}$ ibid.

25 ibid. Alan Redfern and Martin Hunter stated:

"It is less easy to see why the principles of law of the forum state should be taken into account, when an award has been made in another state in accordance with other, no doubt equally valid, legal principles". Ibid. Alan Redfern dan Martin Hunter menyatakan:

"It is less easy to see why the principles of law of the forum state should be taken into account, when an award has been made in another state in accordance with other, no doubt equally valid, legal principles".

${ }^{26} \mathrm{As}$ an evidence of that during this period there have been no proceedings on the enforcement of international arbitral award is, the researcher has searched several documents, including:

a. Collection of Supreme Court Jurisprudences Years 1969 through 2008, the Supreme Court of the Republic of Indonesia;

b. Collection of Supreme Court Awards On Arbitration, the Supreme Court of the Republic of Indonesia, Jurisprudence Project, 1990;

c. Through Internet "Indonesian Law 1949-1989, Chapter 12, Arbitration" pages 239-240; at http://books. 
Convention, there were doubts after Indonesia became an independent and sovereign country. The Chief Justice R. Asikin Kusumaatmadja, argued that such a convention is no longer valid since the Round Table Conference. ${ }^{27}$ This is due there is no statement explicitly and actively by the Indonesian part that our country intended to consider itself bound by the convention. On contrary, Sudargo Gautama argued that although Indonesia has been independent and sovereign, the 1927 Geneva Convention still apply. This is because Indonesia adopts a passive stance on applicability of the conventions since from prior to the recognition of sovereignty. ${ }^{28}$ In this regard, the Geneva Convention that is covered by in the State Gazette of 1933 No. 131 shall still be considered valid, unless the state of RI has annulled it and state explicitly that it will not bound anymore to the international convention.

For an example that Indonesia considers itself no longer bound by a convention by means of declaring it explicitly, can seen when Indonesia declared not participate in the Berne Convention on Copyrights. When Indonesia was about to leave this convention, the Juanda Cabinet expressly declared to the administrative holder of the Berne Convention that the Indonesia did not want to be bound anymore with the convention. ${ }^{29}$

Doubt about implementation of the 1927 Geneva Convention began to be overridden when, in 1958, the UN General Assembly adopted the Convention on the Recognition and Enforcement of Foreign Arbitral Awards in New York on June 10, 1958. ${ }^{30}$ The Convention was signed by 40 countries. Until the end of November 2010, this convention has been adopted by 145 countries. ${ }^{31}$

Since ratification of the 1958 New York Convention by Indonesia, then is viewed from regulation aspect, there should be no more doubts about the enforcement of International Arbitral Awards in Indonesia.

1. Period During Validity of the Presidential Decree No. 34 of 1981 on Ratification of the 1958 New York Convention by the Government of Indonesia

Indonesia has ratified the 1958 New York Convention starting effective as of October 7, 1981, through Presidential Decree (Keppres) No. 34 of 1981 and ha been published in the Statute Book of the Republic of Indonesia of 1981 No. 40.32 This Presidential Decree provides for Ratification of the Convention on the Recognition and Enforcement of Foreign Arbitral

google.co.id

d. Interviews of the researcher the with academicians in the field of international arbitration, Huala Adolf, on May 10, 2009 in Bandung; and

e. Interview of the researcher the with academicians and the Chief Judge of the Supreme Court of the Republic of Indonesia of Special Civil Law, Prof. Dr. Mieke Komar, SH., MCL., on June 3, 2009 in the Supreme Court of the Republic of Indonesia.

${ }^{27}$ Article 5 of the Round Table Conference Agreement stated that "International agreements that are applicable to the territory of the United Republic of Indonesia shall remain valid for that territory as long as the relevant agreements have not been revoked by the Government of Indonesia itself". (See: Sudargo Gautama (c), op.cit., page 146.)

${ }^{28}$ This is the opinion of Prof. Sudargo Gautama that was brought forward in the Asian Law forum in 1973, when he presented his paper entitled “Commercial Arbitration in Indonesia”. (See: Sudargo Gautama (b), ibid., page 210).

${ }^{29}$ Sudargo Gautama (d), op.cit., page. 55.

${ }^{30}$ Priyatna Abdurrasyid, op.cit, page. 244.

${ }^{31}$ Can be seen at http://www.uncitral.org. accessed on November 30, 2010.

${ }^{32}$ Sudargo Gautama (b), op.cit., page. 214. 
Awards. In this Presidential Decree, there are some basic principles: ${ }^{33}$

1) Recognition of foreign arbitral awards;

2) Foreign arbitral award by itself has a self-executing power in Indonesia;

3) However, the self executing nature which is contained in a foreign arbitral award is based on the "reciprocity" principle.

Indonesia's participation in the 1958 New York Convention, was accompanied by two reservations, namely, reciprocity reservation and commercial reservation. ${ }^{34}$

The 1958 New York Convention has been ratified in the Indonesian legal system based on Presidential Decree No. 34 of 1981. This convention is the rules governing the recognition and enforcement of international arbitral awards, this convention is by itself a general rule of arbitration relating to recognition and enforcement of international arbitral awards.

Although the 1958 New York Convention has been ratified by the Government of Indonesia, and most legal experts and practitioners argue that the convention is self-executing ${ }^{35}$, apparently the enforcement of international arbitral awards in Indonesia still encountered obstacles. This is due to the persistence of international arbitration awards that were rejected for enforcement in Indonesia by the Indonesian Supreme Court.

One example of case is the case of PT Nizwar vs. Navigation Maritime Bulgare $^{36}$, the Indonesian Supreme Court award No.2944 K/Pdt/1983 that was decided on November 29, 1984. This case is an example of international arbitration case of the transition period of implementing regulations of the international arbitral awards in Indonesia. This case was filed in the Central Jakarta District Court in $1979^{37}$ and decided on June 19, 1981 (a time prior to Indonesia became a Member of the 1958 New York Convention). However, when the case was filed to the Indonesian Supreme Court in $1983^{38}$, decided on November 29, 1984 (a time after Indonesia became a member of the 1958 New York Convention).

Rejection against enforcement of international arbitral award by the Indonesian court seen again in the case of PT. Bakrie Brothers Vs. Trading Corporation of Pakistan Limited. Pakistan Trading that was based in Karachi Pakistan, has filed an application for enforcement of arbitral award, Award of Arbitration that was stipulated by the Federation of Oils, Seed and Fats Association Limited, No. 2282 dated September 8, 1981 before the South Jakarta District Court against PT. Bakrie Brothers having its domicile in South Jakarta. The request of which has been granted by the Decision of Execution No.fol.22/48/JS/1983 dated February 13, 1984.

As a reason for refusal of enforcement by Bakrie Brothers, have used Article V (1) (b), on where the parties shall be given with sufficient notice of

33 ibid.

${ }^{34}$ See Article 1 paragraph (3) of the 1958 New York Convention.

${ }^{35}$ No more implementing regulation issued by the Government of Indonesia is required, because the convention itself states that the method of enforcement of arbitral award pronounced abroad is the same as those that is applicable to the domestic arbitration awards of the convention members. See: Sudargo Gautama (b), op.cit., page 2.

${ }^{36}$ Erman Rajagukguk, op.cit., page.38 - 40.

${ }^{37}$ Award of the Central Jakarta District Court No. 2288/1979/P, dated June 19, 1981

${ }^{38}$ Award of the Supreme Court of Republic of Indonesia No. 2944 K/Pdt/1983, dated November $29,1984$. 
appointment of the arbitrators or the arbitration proceeding or opportunity to defend himself, right of the defense, and if he feels of not given with such a sufficient opportunity then he is entitled to file objection against the enforcement of arbitral award before the Court.

Regrettably that the Supreme Court did not provide its own consideration, but simply with "it is not obvious in this case the contrary with law or legislation, therefore, the request for Cassation that was filed by the Cassation Applicant Trading Corporation of Pakistan Limited must be declined“.

The aforesaid award shows that the Court has re-examine the merits of the case, whereas the powers conferred upon the Court are limited by Article V (1) (2) of the 1958 New York Convention, that constitute the international commercial arbitration principle, that the national courts are not allowed to interfere in the merit of the case.

From several examples of cases above, it can be said that although Indonesia has been a member of the 1958 New York Convention, there are still refusals of the Supreme Court to enforce the international arbitral awards. The attitude of the Supreme Court that refuses to enforce international arbitral awards, is unacceptable and has received censure and sharp criticisms from various circles, particularly from foreign business players. ${ }^{39}$

In order to overcome the vacancy of procedural law in term of enforcement of international arbitral awards, and at the insistence of the Association of Chambers of Commerce and Industry, then the Supreme Court of the Republic of Indonesia issued Regulation of the Supreme Court of the Republic of Indonesia No. 1 of 1990 on Procedures for Enforcement of Foreign Arbitral Awards in Indonesia.

Expectation of the foreign business players is, upon issuance of such a Regulation of Supreme Court, there will be no more obstacles enforcement of international arbitral awards in Indonesia. Given the Procedural Law on enforcement of international arbitral awards has been provided for in such a Regulation of Supreme Court.

\section{Period During Validity of the Regulation of Supreme Court of the Republic of Indonesia No. 1 of 1990 on Procedures for Enforcement of International Arbitral Awards in Indonesia}

On March 1, 1990, the Supreme Court of the Republic of Indonesia issued a Supreme Court Regulation on Procedures for Enforcement of Foreign Arbitral Awards in Indonesia. Issuance of such a Supreme Court Regulation received acclamation from various circles, particularly the legal practitioners. ${ }^{40}$ The Supreme Court Regulation which contains 9 chapters on procedures for enforcement of foreign arbitral awards in Indonesia, in Article 1 of the Supreme Court Regulation states that "Those who is competent to address issues relating to recognition and enforcement of foreign arbitral awards is the Central Jakarta District Court." Article 2 contains the definition of foreign arbitral award. ${ }^{41}$ Article 3 contains the conditions for a foreign arbitral award

\footnotetext{
${ }^{39}$ M. Yahya Harahap(a), op.cit., page. 337.

${ }^{40}$ That is as written by Erman Rajagukguk in his article entitled "Keputusan Arbitrase Asing Mulai Dapat Dilaksanakan Di Indonesia”, (Suara Pembaruan, June 7, 1990), page II.

${ }^{41}$ That article reads:
} 
can be enforced in the territory of Indonesia. In its Article 4 states that an exequatur (notation on "fiat execution") ${ }^{42}$ from the Supreme Court is required. Administratively, the method is by submitting request for exequatur through the Central Jakarta District Court. The procedure for obtaining this exequatur as contained in Article 5, and procedures for seizure and enforcement of award is set out in Article 6. Article 7 contains costs for application for exequatur.

One of case examples on rejection of enforcement of international arbitral awards by the Supreme Court of the Republic of Indonesia for reason of public orderliness is the case of Yani Haryanto vs. E.D.\& F.Man (Sugar) Ltd (a company having its domicile in the UK). ${ }^{43}$ This case is an example of transitional case from the previous Supreme Court Regulation, because the case was filed in the Central Jakarta District Court in $1988^{44}$ and the Jakarta High Court in $1989^{45}$, and then decided by the Supreme Court on December 14, 1991 after the taking into force of the Supreme Court Regulation ${ }^{46}$ (the Supreme Court Regulation was issued on March 1, 1990).

In the Award of the Supreme Court, it was pointed out that the "judicial award of foreign country of Foreign Arbitration Council, can not be enforced in Indonesia. Unless between the Indonesia and the foreign country has entered into an agreement" thus, the award of the Central Jakarta District Court was confirmed. The Supreme Court of the Republic of Indonesia considered the objections brought forward by ED \& F Man (Sugar) limited are unfound.

The Supreme Court in its Award No. 1205/K/Pdt/1990 dated December 14,1991 has pointed out that it is deemed necessary to "be added also as considerations of this case" namely concerning stipulation of the Supreme Court of the Republic of Indonesia dated March 1, 1991 No. 1 pen Exs/Arb. Int/Pdt/1991 which, although in dossiers of this case was not mentioned, but this closely relates with this case" thus, this consideration is an additional that is deemed by us as "obiter dictum". It was considered later by the Supreme Court "that the aforesaid stipulation is concerning granting the application for exequatur against the award of the Queens Counsel of the English Bar in London, dated 17 November 1989“. Considering that a exequatur stipulation is merely Prima Facie. Thus, such a stipulation is not a legal assessment on the contents of the Agreements made.

In other words, the Supreme Court emphasizes here that the stipulation of exequatur is merely at a glance in nature and can be subjected to review at any time if there is strong legal reason for it. The Supreme Court stated further "considering, that this stipulation of exequatur only gives executorial title to the foreign arbitral award, the enforcement of which subject to the Indonesia

"Foreign arbitral award means an award issued by an Arbitration Board or Individual arbitrator outside the jurisdiction of the Republic of Indonesia, or an award of Arbitration Board or Individual arbitrator that under provisions of law of the Republic of Indonesia is deemed as a Foreign Arbitration award, which is final in accordance with the Presidential Decree No. 34 of 1981 the Statute Book of 1981 No. 40 dated August 5, 1981“.

${ }^{42}$ Fiat Execution means: an affiormative statement to be executed. See: Yan Pramadya Puspa, Kamus Hukum Edisi Lengkap, (Semarang: CV. Aneka Ilmu, 1977), page 378.

${ }^{43}$ Supreme Court of the Republic of Indonesia No. 1203K/Pdt/1990 jo. Civil No. 736/Pdt/G/ VI/1988/PN.JKT.PST jo.PT Jkt No. 485/Pdt/1989/PT DKI.

${ }^{44}$ Award of the Central Jakarta District Court No. 499/Pdt/G/1988, dated June 29, 1989.

${ }^{45}$ Award of the Jakarta High Court No. 486/Pdt/1989/PT.DKI, dated October 14, 1989.

${ }^{46}$ Award of the Supreme Court of the Republic of Indonesia No. 1205.K/Pdt/1990, dated December $14,1991$. 
procedural law." Then the Supreme Court said "since it has been decided in the present subject of case that the relevant sale and purchase contracts of sugar (in which contain this arbitration clause) has been annulled by the Supreme Court have been considered null and void by the Supreme Court, then the stipulation of Supreme Court of the Republic of Indonesia dated March 1, 1991 No. 1 Pen.Extr/Arb.Int/Pdt/1991 becomes irrelevant to be implemented.

The Supreme Court has declined the application for cassation filed by MAN. Arbitral Award of the English Queens Counsel in London could not be enforced. Then, the Central Jakarta District Court did not continue the enforcement of exequatur of MAN and consequence of execution against this arbitral award of the Queens Counsel that was deemed unfound because the principal contracts that contain relevant arbitration clause has been annulled.

The lesson learned from this award of Supreme Court is that an international arbitral award cannot simply be enforced in Indonesia, particularly if it is deemed violating public orderliness applicable in Indonesia. The aforesaid case is the first case after the entry into force of the Supreme Court Regulation on March 1, 1990 the case suit of which was begun before the entry into force of the Supreme Court Regulation. Upon issuance of the Supreme Court Regulation, expectably the enforcement of international arbitral awards will receive more legal certainty.

Another example can be seen in the case of Safic-Alcan \& Cie, vs. PT Foursa Tani Nusa. In the application for exequatur that was filed by SaficAlcan \& Cie - France to the Supreme Court through the Central Jakarta District Court, has attached two Certificates of Indonesian diplomatic representatives, one from the United Kingdom, London, the other from Paris, France. However, in accordance with Article 5, paragraph (4) point (c) of the Supreme Court Regulation No. 1 Year 1990, this is actually excessive because, that is required is just one, namely from the Indonesian Diplomatic Representative of the country where the arbitral award is stipulated.

Another example of case is between Sikinos Maritime Ltd., Vs. PD Perdata Lot. Memorandum of Agreement, dated September 0, 1991, between PT Perdata Lot, having its domicile at Jalan Sutomo540, Medan Indonesia, as the Seller and Sikinos Maritime Ltd., having its domicile in Vallette Malta, has conducted a sale and purchase of vessel " M.T. BUMEUGAH ".

The arbitral award has ordered payment for an amount of compensation to the Buyer by the Seller who was evidentially default because of not performing its obligation to sell the vessel MT BUMEUGAH to the buyer as agreed in the Norwegian Saleform, dated September 20, 1991.

This application for fiat execution has been considered that this arbitral award is concerning the payment for an amount of money of US $\$ 617,046$ plus interest of $6.5 \%$ per annum since December 15,1991 , has been registered with the Central Jakarta District Court and not contrary to the public orderliness, but the request for exequatur was declined by the Supreme Court. ${ }^{47}$ Such a declination made by the Supreme Court of the Republic of Indonesia clearly gave a bad impression, in viewing of the procedure has been conducted out by the business player and no public orderliness was violated.

Essentially, rejection of an international arbitral award, can be conducted by a state, because this is allowed under the 1958 New York Convention.

${ }^{47}$ ibid., page. 239. 
In term of rejection of an international arbitral award, the 1958 New York Convention gives the convention participating countries the opportunity to reject international arbitral awards, if they meet the requirements as set out in Article V (1) of the Convention.

Furthermore, Article V (2) of the 1958 New York Convention also states that the recognition and enforcement of an arbitral award can also be rejected if the competent body of the country where the recognition and enforcement of arbitral award if filed finds:

a) The subject of dispute can not be settled through arbitration based on law of that country;

b) Recognition and enforcement of the award will be contrary to the public orderliness in that country.

As to the rejection of international arbitral awards as referred to in Article V (2) point (b) for reason of contrary to public orderliness, have been practiced by many courts in other countries. It can be seen the application of Article V (2) point (b) that allow the refusal against enforcement of international arbitral awards for reason of public orderliness in several awards of United state Supreme Court and how the United States Supreme Court interprets the public orderliness concept.

In the case between Bremen versus Zapata Off-Shore (5th Circuit, 1972) ${ }^{48}$, the U.S. Supreme Court annulled the award at appellate level stating that the recognition of arbitration clause between the parties will be contrary to the public orderliness. This dispute was between a German company (Bremen) and an American company (Zapata Off-Shore).

In the case between Vimar Seguros y Reaseguros, S.A. versus M/V Sky Reefer (1995) ${ }^{49}$, the U.S. Supreme Court decided that the arbitration clause in a bill of lading can be enforced based on the Federal Arbitration Law, even though such a clause includes dispute resolution through arbitration in Japan based on Japan Law and in the Underlying Contract there was a clause that deviate from the United States law, namely, the Carriage of Goods by Seas Law (COGSA).

In the case between Fitzroy Engineering, Ltd. v. Flame Engineering, Inc., 1994 (N.D. 1994) ${ }^{50}$, the U.S. Supreme Court decided that the arbitral award that rules in favor of the New Zealand contractor over the US sub-contractor can be enforced. The execution Respondent (American company) argued that this arbitral award is contrary to the US public orderliness because of the conflict of interest between the US company's legal counsel and the New Zealand contractor.

Besides as a reason for rejection, the public orderliness is also sometimes used as a reason to request for annulment of an arbitral award. This is as happened in Italy in the case of Freyssinet Terra Armata Srl. V. Tensacciai SpA. ${ }^{51}$

If studying the above cases, public orderliness reason is the reason that

\footnotetext{
${ }^{48}$ Andrew M. Campbell "Refused to Enforce Foreign Arbitral Awards on Public Policy Grounds". https://web2.westlaw.com/find/default.wl?care.html Accessed on November 1, 2007.

${ }^{49}$ ibid.

${ }^{50}$ ibid.

${ }^{51}$ Carlo Ilmari Cremonesi, Recognition and Enforcement of arbitral awards involving antitrust issues, Newsletter Arbitration International Bar Association Legal Practice Division (Vol.12 No. 2, October 2007), page. 43 .
} 
is used most widely by some courts in some countries to refuse or annul the international arbitral awards, not only in Indonesia.

In addition to the examples of cases that were refused in their enforcement of arbitral award, the following are examples of cases in which its request for enforcement of international arbitral awards were accepted in Indonesia, as can be seen in the case of Ecom USA Inc., vs. PT Mahameru Centratama Mills (Stipulation of the Supreme Court No. 4 Pen.Ex'r/Arb.Int/ Pdt/1992, 06-04-1994).

The request for exequatur has been granted by the Supreme Court of the Republic of Indonesia on consideration that the international arbitral award filed has met the requirements as contained in the 1958 New York Convention and in compliance with the procedures as set out in the Supreme Court Regulation.

Another case example of enforceability of an international arbitral award in Indonesia, can be seen in the case of PT Citra Pratama vs. Abdulelah Jamal Al Zamzani Est cs (Stipulation of the Supreme Court No. 1 Pen.Ex'r/Arb. Int/Pdt/1993, June 3, 199352).

In opinion of the researcher, the Supreme Court was proper in granting the application for exequatur of the applicant. This will come to attention of foreign business players, that the international arbitral award in Indonesia can be enforced.

After issuance of the Supreme Court Regulation in 1990, enforcement of international arbitral awards began getting a place in Indonesia because its implementation procedures have been regulated clearly in the Supreme Court Regulation.

To govern better the international arbitration issues in the hierarchy of statutory regulations in Indonesia, in 1999 the government issued the Arbitration Law. In the Arbitration Law, there are several articles that provide for enforcement of international arbitral awards.

\section{Enforcement of International Arbitral Awards After Taking Into Force of the Arbitration Law}

After taking into force of the Arbitration Law, there is transfer of authority to give exequatur. In Article 66 point (d) of the Arbitration Law, stated that "The International Arbitral Award has obtained exequatur from the Chairman of Central Jakarta District Court."

In the Arbitration Law Article 66 point (e), stated that:

"International Arbitral Award that concerns with the Republic of Indonesia as a party to the dispute, can only be enforced after obtaining exequatur from the Supreme Court of the Republic of Indonesia, which is subsequently delegated to the Central Jakarta District Court."

As to the matter of arbitral award as referred to in Article 66 point (e), to which a party is the State of the Republic of Indonesia, since the taking into force of the Arbitration Law until to date, there has not been an example of case. ${ }^{53}$

52 Tineke L.T. Longdong, ibid., page 231-235.

${ }^{53}$ This is different from the case of investment dispute that has ever occurred between the Republic of Indonesia (The Indonesia Investment Coordinating Board) that was sued by PT Amco Asia Ltd. In the dispute regarding Hotel Kartika Plaza before the ICSID arbitration institution in Washington in 1981. 
After taking into force of the Arbitration Law, there have been four awards of international arbitration cases that come to the Supreme Court, in relation to the existence of cassation legal effort of the party who feel aggrieved. In this sub- section, the researcher will discuss one award of the Supreme Court that declined the enforcement of international arbitral award, namely in the case of Bankers Trust Co. Vs. PT Mayora Indah. Awards that will be discussed later, is an award regarding annulment of international arbitral award by the Central Jakarta District Court, but such an award was later annulled by the Supreme Court, namely in the case of PT Pertamina vs. Karaha Bodas Company.

Concerning refusal of enforcement of international arbitral award originating from London by the Central Jakarta District Court, Bankers Trust Company filed an appellate legal effort to the Supreme Court of the Republic of Indonesia. However, the award of the Supreme Court was to reaffirm the award of Central Jakarta District Court, which refused enforcement of international arbitral award. The Supreme Court of the Republic of Indonesia has reaffirmed the Award of Central Jakarta District Court, which refused enforcement of international arbitral award originating from London. However, consideration of the Supreme Court did no assess anymore the substance of arbitration agreement, but emphasizing more on the formal requirements of the application for cassation.

If studying the award of the Supreme Court on the above case, public orderliness reason that is made as one of basis by the Central Jakarta District Court in refusing the enforcement of international arbitral award originating from London, was not mentioned again in the considerations of the Supreme Court.

The lesson that can be taken is, although Indonesia has had the Arbitration Law, the Supreme Court still has authority in term of refusing enforcement of international arbitral awards, if the Supreme Court is in the opinion that the international arbitral award has been files not in conformity with the prevailing law provisions.

In addition to the above case, there is another international arbitral award from London that was rejected by the Central Jakarta District Court. This relates to the absence of arbitration clause which is one of essential requirements in an arbitration agreement. One of the case examples is the dispute between Bankers Trust Company Vs. PT Jakarta International Hotel Development (JIHD) in 1999. In this case, the award of London Arbitration has been attained, however the law attorney of JIHD stated that there has been no arbitration clause in the dispute concerning SWAP transaction, thus, in the enforcement such an international arbitral award was declined by the Chairman of the Central Jakarta District Court and it was confirmed by the Appellate Award of the Supreme Court of the Republic of Indonesia through Decision No. 03 K/Ex'r/Arb.Int/Pdt/2000. ${ }^{54}$

As to the refusal of enforcement of international arbitral award for reason of public orderliness, has also occurred in the Award of the People's Republic of China Supreme People's Court, July 5, 2004..$^{5}$ This award related

${ }^{54}$ Provisional Judgment No. 46/Pdt.G/1999/PN. Jaksel, jo Award No. 004/Pdt/Arb. Int/1999/ PN.Jkt.Pst. Award of the Supreme Court No. 04 K/Ex'r/Arb.Int/Pdt/2000, dated September 5, 2000.

${ }^{55}$ Albert Jan Van Den Berg (General Editor), Yearbook Commercial Arbitration, Vol. XXXI-2006, 
to a dispute between Wei Mao International Co. Ltd. (Hong Kong SAR) as the Plaintiff, and Shanxi Tianli Industrial Co. Ltd. (China PR).

In June 1998, Shanxi Tianli Industrial Co. Ltd. (Tianli) entered into a contract of coal trading with Wei Mao International Co. Ltd. (Wei Mao) in Hong Kong. The contract contains an arbitration clause which states that the Parties agree to settle any disputes that might arise from the contract in the International Chamber of Commerce (ICC) by using the UK Law, if within 30 days the Parties fail to settle the dispute by means of negotiation.

During the term of this contract, a dispute occurred in the implementation of this business. In this case, Wei Mao submitted this dispute to ICC arbitration institution in Hong Kong. On June 3, 1999, the ICC appointed Mr. John Luk of Hong Kong as the sole arbitrator. This arbitral award was ruled in favor of Wei Mao who will receive a compensation of US\$341,447.97 plus interest. Wei Mao submitted application for enforcement of this arbitral award to the Tai Yuan Intermediate People's Court. Tianli declined this application for enforcement and submitted such a declination to the Tianli Court.

Refusal of enforcement of international arbitral awards on the ground for reason of public orderliness, has also been made by the Court in Den Haag, in the case of Marketing Displays International Inc vs. VR Van Raalte Reclame B.V. (Recthbank The Hague, 27 May 2004 and Grechtshof, The Hague, 24 March 2005). ${ }^{56}$

Public orderliness is sometimes also made as a basis in a suit of annulment of international arbitral award. This is as occurred in Indonesia. The only international arbitral award that is applied for its annulment after the taking into force of the Arbitration Law is the Swiss Arbitral Award, Geneva dated December 18, 2000, namely in the Case of PT Pertamina vs. Karaha Bodas, Award of the Supreme Court No. 01/BANDING/WASIT.INT/2002.

Dispute between PT Pertamina and KBC, invited attention and comments from legal analysts in international arbitration sector. Thing that got most attention is particularly the annulment of Swiss international arbitral awards by the Central Jakarta District Court. One of them is Catherine A. Giambastian who was in the opinion that there is a country that should have primary jurisdiction. Forum that should be competent to annul the arbitral award is the place of issuance of arbitral award and the state whose procedural law is used. For that reason, since the procedural law used the Swiss law and since the Swiss is the place where the award was issued, then the only state that has primary jurisdiction is Switzerland to examine this case. ${ }^{57}$

According to Noah Rubins, there is a major mistake made by the Central Jakarta District Court in interpreting provisions in the 1958 New York Convention in the Case of Karaha Bodas. ${ }^{58}$ The court held that Indonesia has the right to annul the Geneva arbitral award because based on Article V (1) (e), a foreign arbitral award can be annulled by the competent authority in the country "...in which, or under the law of which, that award was made". The words "under the law of which" was interpreted by the court as a forum, whose

\footnotetext{
(The Hague, Kluwer Law International), page. 624.

${ }^{56}$ ibid., page. 808.

${ }^{57}$ Catherine A. Giambastian, "Recent Development: Lex Loci Arbitri and Annulment of Foreign Arbitral Awards in U.S. Courts”, American University International Law Review (2005).

${ }^{58}$ Noah Rubins, loc.cit.
} 
law has been chosen by the parties as the governing law for their contract, namely the country that is competent to annul the foreign arbitral award.

Yet, according to Noah, Articles V and VI distinguish two types of courts, namely the court in the country of origin where the arbitral award was made ("primary court") and the court that is asked to enforce the arbitral award ("secondary court"). ${ }^{59}$ This is the primary court that can annul an arbitral award, in this case the courts in Swiss, rather than the Jakarta Court, because it is only a "secondary court". This is in conformity with the existing practices, as shown by the case of "Standard Electric Corp. v. Bridas Sociedad Anónima Petrolera Industrial y Comercial"60, in which the United States District Court decided that the court that is competent to annul the arbitral award is the court of Mexico, rather than the American courts, because Mexico is the country in which the award has been made.

This case is in line with the award of the Fifth Circuit of America that has rejected argumentation of Indonesia as the "primary court" when seeking to ask for annulment of the Geneva arbitral award in Texas by concluding that "the law that is applicable to the arbitration procedure is lex arbitri, law of the arbitration domicile, which in this case is the Swiss law".61 The Fifth Circuit also decided that Pertamina is, based on the estoppel theory ${ }^{62}$, considered unable anymore to claim that this is the Indonesian law that governs the arbitration proceeding because Pertamina has first relied on the Swiss procedural law, prior to contradict its own opinion now..$^{63}$ This is shown by:

1. Bringing the suit to Swiss first prior to submitting to the Indonesian court. ${ }^{64}$

2. Not only argued that the Swiss law applies to arbitration proceedings, but also has many times made the Swiss law a legal basis in arguing with the arbitration panel. ${ }^{65}$

3. Pertamina did not argue that the Indonesian law is applicable to the trial process during the arbitration proceedings or when it filed appeal to the Swiss court. 66

4. When Pertamina seeking to prevent the Swiss arbitral award from being enforced by the Texas District Court, Pertamina argued that the Swiss arbitration law applies and the Swiss courts have jurisdiction to hear the suit of Pertamina. ${ }^{67}$

According to Noah, the Indonesian court was error in applying the Arbitration Law. Article 70 only gives three reasons for annulling a foreign arbitral awards in Indonesia: (1) If either party provides false documents,

\footnotetext{
${ }^{59}$ V.S. Deshpande, Jurisdiction over "Foreign" and "Domestic" Awards in the New York Convention 1958, 7 Arb. Int'l 123, 126 (1991).

${ }^{60}$ International Standard Electric Corp. v. Bridas Sociedad Anónima Petrolera Industrial y Comercial, 745 F. Supp. 172, 177 (S.D.N.Y. 1990).

${ }^{61}$ Karaha Bodas IV, 364 F.3d at 291-92.

${ }^{62}$ This theory is also called as detrimental reliance, meaning existence of corresponding intention between the parties if the counterparty has conducted something as a result of the actions of the other party that is deemed as an offer for a contract. See: repository.unand.ac.id/1037/1/virza_benzani, rtf. Accessed on October 30, 2010.

63 ibid., at 293-94.

64 ibid.

${ }^{65}$ Karaha Bodas , loc.cit..

${ }^{66}$ ibid.

67 ibid.
} 
(2) If any key document is concealed by either party from the other party, or (3) If either party is involved in any fraudulent action during the arbitration proceeding. Pertamina in this case did not provide any evidence to the court that can satisfy one of the reasons above. The Central Jakarta District Court even used the Elucidation of Article 70 to annul the Geneva arbitral award stating that "the reasons for rejecting the arbitral award are, among other things, as set forth in Article 70".

If analyzing the case of PT Pertamina vs. KBC in term of judge competence, in the text of the International Civil Procedural Law, there are two types of principles of suit submission in the defendant's domicile (presence). The competence to adjudicate is based on, first of all, " the basis of presence", namely, that in general, jurisdiction of a country is recognized covering territorially all people and things that are within its territorial borders. According to this principle, the competent court is the court in the defendant's domicile. ${ }^{68}$

In addition, there is a "principle of effectiveness", meaning that, in general, the judge will only give a decision which essentially will be implemented later. It is certainly guaranteed the most if the suit is filed before the Court where the defendant (and the things) are domiciling. ${ }^{69}$

As to the reasons of KBC submitting the request for enforcement of Swiss arbitral award to other countries outside Indonesia are, in the opinion of the researcher, because $\mathrm{KBC}$ gives preference to the effectiveness principle, because in Texas, Canada, Honking and Singapore, PT Pertamina owns properties.

Concerning dispute that occurred between PT Pertamina and KBC, several expert witnesses from various countries were invited to be consulted. The following are some of the opinions expressed by the experts in the field of international arbitration from several countries, including the opinion of Prof. Van Den Berg. ${ }^{70}$

According to Prof. Van Den Berg, an Arbitration Expert of the Netherlands, that the "Country of Origin" is a country whose arbitration law is used for relevant overseas arbitration and award of this relevant arbitral award has an important legal effect to the relevant international arbitration.

In the case between PT Pertamina (Parser) versus Sahara Bodas Company (KBC) and PT PLN based on the Joint Operation Contract (JOC) and the Energy Sales Contract (ESC), which has been decided by the Geneva arbitration assembly of Swiss, and then annulled by the Central Jakarta District Court, obviously the parties choose their substantive law if the Indonesian law Article 13 of the Joint Operation Contract (JOC) and Article 8 of the Energy Sales Contract (ESC), however the place of arbitration is in Geneva Swiss meaning the State of Indonesia as the Country of Origin whose law is used for arbitration that was decided in Geneva Swiss.

Conclusion of the opinion of Prof. Van Den Berg is that the 1958 New

${ }^{68}$ Sudargo Gautama(l), Hukum Perdata Internasional Indonesia, Volume III, Part 2, the 8th Book, (Bandung: Alumni Publisher, 1987), page 213.

69 ibid.

${ }^{70}$ Albert Jan Van Den Berg, "Expert Reeport", a legal opinion presented in the court trial in relation to execution of the Geneva Arbitration Award before the United States District Court for the Southern District of Texas, March 29, 2002. Jan Van Den Berg is a Law Professor of Erasmus University Rotterdam and also the Secretary General of the Arbitration Institute of the Netherlands 
York Convention expressly states that the parties to an arbitration agreement have agreed upon an arbitration that is to be used different from the law in which the award has been made, in this case the award was made in Swiss, but the parties may choose the Indonesian arbitration law. Indonesia as the country of origin, namely the Country whose law is used, is the first country to which a lawsuit for annulment or waiver of foreign arbitral award can be filed (exclusive jurisdiction).

If the parties have agreed upon an arbitration law that is different from those where the arbitration is uttered or heard. This non-arbitration country that has been chosen by the parties to this arbitration is the proper jurisdiction to submit a proceeding for annulment. Such an opinion of Prof. Van den Berg is in line with the Article 5 paragraph (1) point (e) which states the reason for rejecting an arbitral award is that this award has been waived by the competent authority in the country in which, or under the law of which, the award was made. So, it is proper that Indonesia is as the place of submission for annulment of Arbitral Award of Geneva Swiss. The principle of Article 5 paragraph (1) point (e) of the 1958 New York Convention: "The country in which or under the law of which the award was made".

The 1958 New York Convention, Article 5 paragraph (1) point (e), has exclusive competence to determine whether or not to annul a foreign arbitral award. The 1958 New York Convention does not provide for annulment of award but only govern the procedures for rejection of foreign arbitral awards, thus the Country in which or under the law of which the award was made as a material to annul the relevant award conforms to its own law of the country of origin. Article 6 of the 1958 New York Convention, states the courts in another country can also suspend enforcement of arbitral laws pending the annulment in the country of origin.

Meanwhile, according to Prof. W. Michael Reisman ${ }^{71}$, the primary jurisdiction is the competent authority of the country under the law of which this award has been made (Article 5 paragraph (1) (e) of the 1958 New York Convention. In that relation the Joint Operation Contract (JOC) and the Energy Sales Contract (ESC) in which PT Pertamina (Parser) against Sahara Bodas Company (KBC) and PT PLN is the only one that entered. In the court trial between PT Pertamina (Parser) against Sahara Bodas Company and PT PLN, initially the relevant contracts have stated that the Indonesian law applies because the Geneva Swiss arbitration must use the Indonesian law. There are 3 specific reasons for taking such a stance. Firstly, the agreement which has been made clearly stated that the parties shall use the Indonesian arbitration law. Secondly, in fact the Switzerland law shall not be used in the governing procedural law for this arbitration, particularly in relation to the efforts to ask for legal assistance, both before arbitral award and authorizes the arbitrators to use the law with which this case has the closest connection. In the event they have not chosen a specific substantive law and in this present case other than the law of Indonesia. According to Professor Reisman, analogously the same method can be used to determine the procedural law if the parties have not expressly determined their choice toward the same. Thirdly, the United Nations on Commission Trade Law (UNCITRAL) Arbitration Rules

${ }^{71}$ Prof. Reisman is a Professor of International Law in the United States. As to his legal opinion, can be seen in: Sudargo Gautama (a), op.cit., page 73. 
that have been chosen by the parties require the arbitrators to determine the substantive law by using the conflict of laws (law principles among International Civil law (HPI) systems which they consider must be used. Once again, in accordance with the reasons as described above, it will only refer to Indonesian arbitration law. Similarly, the same method can be used to determine the applicable procedural law, therefore, which arbitral law to be used is important in determining what is the primary jurisdiction according to the 1958 New York Convention.

If the parties fail to choose which law is desired, then the procedural law system which has the closest connection is to be used. Since the project is in Indonesia, the energy seller is in Indonesia, as well as the substantive law is in Indonesia, then, obviously, the closest connection for liability of this project is the Indonesian law, it can also use the international civil law principles (conflict of law) which, according to the HPI Swiss refers to the Indonesian law. Prof. Reisman also seen no use of law that has been chosen by the parties in the arbitral award of Geneva Swiss, thus, it is proper that PT Pertamina (Parser) applied for annulment through the Central Jakarta District Court.

Prof. Hans Smith ${ }^{72}$, a Professor of Columbia University, was of the opinion that the Swiss Court has dismissed the claim from PT Pertamina (Parser), because PT Pertamina evidentially did not make payment of deposit as has been determined by this Swiss Court. Therefore, PT Pertamina (Parser) has subjected itself to accept jurisdiction of the Swiss Court that has rejected the suit for annulment. Thus, according to Hans Smit, no more annulment can be filed. In this case, the "nebis in idem" principle applies. And, according to him, this principle has been accepted throughout the world. According to him, it began with the Roman law, then accepted in the law of the Netherlands and also in the laws of Indonesia. Therefore, based on the neb is in idem principle, PT Pertamina (Parser) and PT PLN can not anymore submit a lawsuit for annulment.

This Hans Smith's opinion was contested by Sudargo Gautama on the ground that the claim by PT Pertamina (Parser) in Swiss have not entered the substance of case (substantive law), the substance of case has not been examined so that it could not be said as nebis in idem, and therefore, this is the Indonesian Court that is competent to examine the suit for annulment of Swiss arbitration.

Prof. Pieter Sanders ${ }^{73}$ (an international arbitration expert), argued that there is only one competent authority and this is interpreted in double, where this is a court of the country in which this arbitral award has been made , or the court of the country whose law has been used, which in the case of judgment between PT Pertamina (Parser) against Sahara Bodas Company (KBC) and PT PLN that was decided by arbitration of Geneva Swiss, then its annulment must be conducted in Indonesia merely as the country whose law was used in the arbitration proceeding, the case of which is in conformity with the contents and reading of the Article V paragraph (1) (e) of the 1958 New York Convention. Different with the opinion of Eric A Schwartz, since the place where the arbitral award was decided is Swiss, then its annulment of award must be in Swiss (under the law of which the award was made) Article

\footnotetext{
${ }^{72}$ ibid., page. 99.

73 ibid., page. 125 .
} 
V paragraph (1) (e) of the 1958 New York Convention.

In the opinion of Sudargo Gautama, the birth of international arbitral award that was awarded in Swiss on December 18, 2000, in the case between Sahara Bodas Company (KBC) as the Plaintiff against PT Pertamina (Parser) and PT PLN as the Defendant and the co-defendant is in relation to the termination of the contract or the cooperative agreement between Sahara Bodas Company (KBC) and PT Pertamina (Parser), namely the cooperation contract for construction and geothermal energy, in which PT Pertamina (Parser) acted as the Responsible Part for Geothermal Sector and Karaha Bodas Company (KBC) acted as the Contractor that is required to develop geothermal energy and to construct and develop the power generating as specified in the Joint Operation Contract (JOC) dated November 28, 1994 after which the outputs of the power plant was sold to PT PLN as the buyer that was described in the Energy Sales Contract (ESC) dated November 28, 1994.

Against the award of Central Jakarta District Court, KBC filed an appeal to the Supreme Court. The Supreme Court has, on March 8, 2004, decided that the Central Jakarta District Court has misapplied the law to this case, thus must should be annulled (Award Number: 01/BANDING/WASIT.INT/2002). The Supreme Court decided Pertamina must pay for compensation to KBC in accordance with the award at the first instance.

The researcher agrees with the opinion of the Supreme Court of the Republic of Indonesia stating that the Central Jakarta District Court is not competent to annul the arbitral award that has been awarded in Geneva, Swiss. When studying the applicable law in the case above, there are at least three related legal systems in the arbitration process. The substantive law is the Indonesian law, the Procedural law is UNCITRAL and the lex arbitri is the Swiss Law. Court that has authority in term of annulment of an international arbitral award is the court in the Country where the arbitral award is uttered. This is in compliance with those as provided for in Article 5 paragraph (1) point (e) of the 1958 New York Convention.

In this case, the Supreme Court has been appropriate in deciding the matter of annulment of international arbitral award that was conducted by the Central Jakarta District Court. The legal basis used by the Central Jakarta District Court, namely Articles 70 through 72 of the Arbitration Law, is until now still posing difference of interpretations from the practitioners, academics, and judges in the courts.

One of the international arbitration cases that was also appealed to the Supreme Court is the case between Astro All Asia Networks Plc (Astro) and PT. Ayunda Prima Mitra (PT APM), a subsidiary of Lippo. PT APM as the owner of PT Direct Vision together with the Astro Group, in which Ayunda held 49\% of shares. And the rest 51\% was held by Silver Concord. Ayunda Prima itself, was owned by PT First Media, 99\%, in the form of the interest value of Rp. 34.54 million and PT Margayu Vantri Chantiqa with interest value of Rp. 35 thousand (1\%).

According to the researcher, refusal of enforcement of arbitral award originating from the SIAC by the Central Jakarta District Court and the Supreme Court of the Republic of Indonesia, indicates the lack of conduciveness of Indonesia country for enforcement of international arbitral awards. This may have adversely effect to the foreign businessmen who will 
apply for enforcement of international arbitral awards in Indonesia. ${ }^{74}$ One of legal experts and practitioners considered that such a refusal of international arbitral award, gives significant adverse effect on the confidence of foreign investors or foreign businessmen in Indonesia. ${ }^{75}$

\section{The role of the Supreme Court of the Republic of Indonesia In Enforcement of International Arbitral Awards After Taking Into Force of the Arbitration Law}

The Supreme Court of the Republic of Indonesia is as the highest judicial institution in Indonesia. In Article 11 of Law No. 4 of 2004 on Judicial Power, provides for functions and authorities of the Supreme Court of the Republic of Indonesia. As the state highest judicial body, the Supreme Court has, among other things, the authority to :

a. Adjudicate at cassation level the ruling awarded at the last level by the courts throughout the court environment below the Supreme Court;

b. Test the statutory regulations below the laws against the laws;

c. Other authorities granted by the law.

Regarding the third authority of the Supreme Court, in this case it can be said that the Supreme Court of the Republic of Indonesia has the authority to either order of enforcement of international arbitral awards or reject its enforcement in Indonesia.

After taking into force of the Arbitration Law, the Supreme Court of the Republic of Indonesia has ceased to have the authority to give exequatur to the international arbitral award. This authority lies on the Chairman of the Central Jakarta District Court. As the highest level legal institution, the Supreme Court has only the authority to supervise and ensure the enforcement of the international arbitral award, as long as the international arbitral award meets the requirements to be implemented within the territory of Indonesia.

Some of source-persons originating from academics and practitioners argue, despite the Arbitration Law does not expressly declare on the revocation of the Supreme Court Regulation, but in term of legislation hierarchy, the provisions on the procedure for enforcement of foreign arbitral awards in Indonesia as contained in the Supreme Court Regulation was not valid anymore since the enactment of the Arbitration Law. ${ }^{76}$ This is in conformity with the principle of "Lex superior derogate lex inferiori (the higher regulation excludes the lower regulation)“.

However, another opinion came from the judges in the courts, that for the Supreme Court institution internally, this Supreme Court Regulation

\footnotetext{
${ }^{74}$ Based on data in the Central Jakarta District Court as at November 30, 2010, since the rejection of Arbitral Award of the SIAC in the case of PT Astro International vs. PT Ayunda Prima Mitra, no more application for international arbitral award has been registered with the Central Jakarta District Court.

${ }^{75}$ That was pointed out by Todung Mulya Lubis, in Media Indonesia.com on Tuesday, February 23, 2010.

${ }^{76}$ H.A.S. Natabaya, Sistem Peraturan Perundang-Undangan Indonesia, (Jakarta: Sekretariat Jenderal Mahkamah Konstitusi RI 2006), page. 38. A similar opinion was stated by a former Chairman of Central Jakarta District Court, H. Cicut Sutiarso, SH., MH., on June 21, 2007 in Jakarta. Similarly, the opinion from the Chairman of the Central Jakarta District Court, Hj. Andriani Nurdin, SH., MH., at the time in the interview of the researcher in the Central Jakarta District Court, 10 September 2008.
} 
is still valid, given that the substance that is regulated in the Supreme Court Regulation is procedural in nature to the Supreme Court and not regulated in the Arbitration Law.

In the opinion of the researcher, if studying the substance that is provided for in the Supreme Court Regulation, it can be concluded that the Supreme Court Regulation is technical in nature and internally still valid to the Supreme Court. In addition, non invalidity of the Supreme Court Regulation in the Arbitration Law, also indicates that the Supreme Court Regulation still applies to for the Supreme Court of the Republic of Indonesia institution internally.

This is particularly seen in Chapter III of the Supreme Court Regulation Article 5, which governs the Procedures for Application for exequatur and in the Chapter IV of the Supreme Court Regulation Article 6, that governs the Procedures for Attachment and Award Enforcement.

If connected to the Arbitration Law, the enforcement of this Supreme Court Regulation relates with the provisions in Article 66 point (e) of the Arbitration Law, stating:

"International Arbitral Award that concerns with the Republic of Indonesia as a party to the dispute, can only be enforced after obtaining exequatur from the Supreme Court of the Republic of Indonesia, which is subsequently delegated to the Central Jakarta District Court."

The procedure for granting of exequatur from the Supreme Court of the Republic of Indonesia, is conducted based on the provisions in the Supreme Court Regulation, such provisions in the Supreme Court Regulation are not provided for in the Arbitration Law.

Based on the difference of substance as provided for in the Supreme Court Regulation and the Arbitration Law, the researcher is of the opinion that the Supreme Court Regulation remains valid until nowadays despite of the Arbitration Law has been published. However, the validity of the Supreme Court Regulation is internal in nature, only within the auspice of the Supreme Court of the Republic of Indonesia, considering the substance that is regulated in the Supreme Court Regulation if technical in nature to the Supreme Court institution.

In order to support the researcher's opinion, the researcher conducted interviews with Professor of Legislation Science of FHUI and also acting as Constitutional Justice in the Constitutional Court, Maria Farida I. Suprapto. ${ }^{77}$ According to her, between the Supreme Court Regulation and the Arbitration Law, a comparison cannot be made by using the "lex superior derogate lex inferiori" principle, because the Supreme Court Regulation and the Arbitration Law are of different levels and different types. The Supreme Court Regulation is internal in nature and is excluded in the hierarchy of legislation. Thus, with enactment of the Arbitration Law does not invalidate the Supreme Court Regulation.

\section{Conclusions}

The role of the Supreme Court of the Republic of Indonesia as the Guardian of the Award has not been seen in the period after taking into force

\footnotetext{
${ }^{77}$ Interview on June 3, 2009 in the Constitutional Court, Jakarta.
} 
of the Arbitration Law. This can be studied from the three cases that were rejected for enforcement at cassation level in the Supreme Court in the case of Bankers Trust vs. PT Mayora Indah, the case of Bankers Trust vs. Jakarta International Hotel Development, and the case of PT Astro International vs. PT Ayunda Prima Mitra. The rejection of the two arbitral awards from London is a refusal that reaffirmed the ruling of the Central Jakarta District Court that rejected the enforcement of international arbitral award for reason of violation of the public orderliness principles. Rejection of international arbitral award was also made by the Supreme Court of the Republic of Indonesia against the arbitral award of the SIAC in the case of Astro, which was a reaffirmation of rejection of international arbitral award from the Central Jakarta District Court. In the case of PT Astro above, the Supreme Court has been less careful in evaluating considerations of the Chairman of Central Jakarta District Court concerning refusal of international arbitral award from the SIAC.

The role of the Supreme Court of the Republic of Indonesia as the Guardian of the Award can be seen in the enforcement of the arbitral award from Swiss, Geneva, namely in the case of PT Pertamina vs. Karaha Bodas Company. In this case, the Supreme Court of the Republic of Indonesia has annulled the International Arbitral Award that was issued by the Central Jakarta District Court in 2002. The Supreme Court considered, that the Central Jakarta District Court was wrong in applying the governing law in the relevant case.

As a general conclusion, in term of enforcement of international arbitral awards in Indonesia, the Supreme Court of the Republic of Indonesia has not played roles maximally as the Guardian of the Award/Guardian of the Law.

\section{Bibliography}

Books

Abdurrasyid, Priyatna. Arbitrase \& Alternatif Penyelesaian Sengketa. First print. Jakarta: PT Fikahati Aneska in cooperation with Badan Arbitrase Nasional Indonesia, 2002.

Adolf, Huala. Arbitrase Komersial Internasional. Jakarta: Rajawali Press, 1991.

------. Pelaksanaan Keputusan Badan Arbitrase Komersil Intenasional Menurut Konvensi New York 1958, in the Varia Peradilan, No.58, July 1990. Jakarta: Ikatan Hakim Indonesia, 1990.

------. Hukum Arbitrase Komersial Internasional. Jakarta : Radjagrafindo, 1994.

------. Dasar-dasar Hukum Kontrak Internasional, second print, Bandung: Refika Aditama, 2008.

Allan, David E. Asian Contract Law (A Survey of Current Problems). Australia: Melbourne University Press, 1969.

Bidara, O. dan Martin P. Bidara. Hukum Acara Perdata. Second print (Jakarta: Pradnya Paramita), 1997.

Black, Henry Campbell. Black's Law Dictionary. Revised fourth edition. St.Paul, Minnesota: West Publishing Co, 1968.

Born, Gary B. International Commercial Arbitration in the United States: Commentary and Materials. Netherlands: Kluwer Law and Taxation Publishers, 1994.

Cohn, Ernest et.al. Handbook of Institutional Arbitration in International Trade. North Holland, Amsterdam: 1977.

David, Rene. Arbitration In International Trade. Deventer/The Netherlands: Kluwer, 1985. 
Dermanto Latip, Yansen. Pilihan Hukum Dan Pilihan Forum Dalam Kontrak Internasional. Jakarta : Post Graduate Program Publicher FHUI, 2002.

Elkouri, Frank and Edna Elkouri. How Arbitration Works. Washington D.C., 1974.

Gautama, Sudargo. Arbitrase Dagang Internasional. $1^{\text {st }}$ Print. Bandung : Alumni, 1979.

------. Hukum Perdata Internasional Indonesia. Third Edition Part I. Seventh Book. Second print. Bandung : Alumni, 1981.

------. Soal-soal Aktual Hukum Perdata Internasional. 1st Print. Bandung : Alumni, 1982.

------. “Konsep Rancangan Undang-Undang Hukum Perdata Internasional Indonesia”, presented in the Workshop of Indoneisan International Civil Law (Lokakarya Hukum Perdata Internasional Indonesia), held by Badan Pembinaan Hukum Nasional the Ministry of Justice RI, in Jakarta September 29, 1983.

-----. Kontrak Dagang Internasional. Bandung: Alumni, 1983.

------. Masalah-Masalah Baru Hukum Perdata Internasional. Bandung : PT. Alumni, 1984.

------. Himpunan Perundang-undangan Hukum Perdata Internasional Sedunia (Asing - Indonesia ). $2^{\text {nd }}$ Print. Bandung : Alumni, 1984.

-----. Hukum Perdata Internasional Hukum yang Hidup. Bandung : Alumni, 1984.

------. Aneka Masalah Hukum Perdata Internasional. $1^{\text {st }}$ Print. Bandung : Alumni, 1985.

-----. Warga Negara dan Orang Asing. $4^{\text {th }}$ Print. Bandung : Alumni, 1987.

------. Perkembangan Arbitrase Dagang Internasional Di Indonesia. Bandung : PT. Eresco, 1989.

------. Aneka Masalah Dalam Praktek Pembaharuan Hukum Di Indonesia. $1^{\text {st }}$ Print. Bandung : PT. Citra Aditya Bakti, 1990.

------. Hukum Dagang Dan Arbitrase Internasional. $1^{\text {st }}$ Print. Bandung : PT. Citra Aditya Bakti, 1991.

------. Hukum Perdata Internasional Indonesia. First Edition, book $1.5^{\text {th }}$ Print. Bandung: Alumni, 1992.

------. Hukum Perdata Internasional Indonesia. Second Edition part 4, the fisrth book. Bandung : Alumni, 1995.

------. Indonesian Business Law. 1 ${ }^{\text {st }}$ Print. Bandung : PT. Citra Aditya Bakti, 1995.

------. Aneka Hukum Arbitrase (Ke Arah Hukum Arbitrase Indonesia Yang Baru. Bandung : PT. Citra Aditya Bakti, 1996.

------. The Commercial Laws of Indonesia. $1^{\text {st }}$ Print. Bandung : PT. Citra Aditya Bakti, 1998.

------. Hukum Perdata Internasional Indonesia. Third Print. Third Edition part 2. The $8^{\text {th }}$ Book. Bandung : Alumni, 1998.

------. Undang-Undang Arbitrase Baru 1999. $1^{\text {st }}$ Print. Bandung : PT. Citra Aditya Bakti, 1999.

Himpunan Peraturan-Peraturan Baru Bidang Hukum Ekonomi Yang Penting Untuk Praktek Sehari-hari. $1^{\text {st }}$ Print. Bandung : PT.Citra Aditya Bakti, 2001.

Indonesia dan Konvensi-Konvensi Hukum Perdata Internasional. $1^{\text {st }}$ Print. The third Edition. Bandung : PT. Alumni, 2002.

Arbitrase Luar Negeri dan Pemakaian Hukum Indonesia. $1^{\text {st }}$ Print. Bandung : PT. Citra Aditya Bakti, 2004.

Harahap, M.Yahya. Arbitrase. Jakarta: Sinar Grafika, 2004.

------. Ruang Lingkup Permasalahan Eksekusi Bidang Perdata. Third Print. Jakarta: Sinar Grafika, 2007.

Perlawanan Terhadap Eksekusi Grose Akte serta Putusan Pengadilan dan Arbitrase Dan Standar Hukum Eksekusi, second print, Bandung: PT. Citra Aditya Bakti, 1996. 
Hartono, Sunarjati. Pokok-pokok Hukum Perdata Internasional Indonesia. $1^{\text {st }}$ Print. Bandung : Binacipta, 1976.

------. In Search of New Legal Principles. Bandung: Binacipta, 1982.

------. Kapita Seleka Hukum Ekonomi. Jakarta: Binacipta, 1976.

Hunter, Martin et.al. The Freshfields Guide to Arbitration and ADR Clauses in International Contracts. Deventer: Kluwer Law, 1993.

I Sriro, Andrew. Sriro's References on Indonesian Arbitration Law. Jakarta: Sriro's Legal Education Series, 2000.

Janvan Den Berg, Albert. The New York Arbitration Convention of 1958. Netherlands: Kluwer Law \& Taxation Publishers, 1981.

Khairandy, Ridwan. Itikad Baik Dalam Kebebasan Berkontrak, Jakarta: Post Graduate Program FHUI, 2003.

Kusumah Atmadja, Asikin Z. Commercial Arbitration, Present and Future Role of Commercial. Jakarta: The Law Association for The Asia And The Western Pacific, 1973.

------. Arbitrase Perdagangan Internasional. Bunga Rampai Eksekusi Putusan Arbitrase Asing. Jakarta: The Sureme Court of the Republic of Indonesia, 1988.

Longdong, Tineke Tuegeh. Asas Ketertiban Umum Dan Konvensi New York 1958. Bandung : PT. Citra Aditya Bakti, 1998.

Lukman, Dahnidar. Klausul Arbitrase ICSID Dalam Persetujuan Penanaman Modal Asing di Indonesia. Jakarta: Disertation of Post Graduate Program FHUI, 1999.

Lynch, Khaterine. International Commercial Arbitration (Applicable Laws In International Commercial Arbitration) : Introduction, page 3.

Prodjodikoro, Wirjono. Asas-Asas Hukum Perdata Internasional. Second print. Jakarta : Van Dop \& Co, 1954.

Purbacaraka, Purnadi dan Agus Brotosusilo. Sendi-sendi Hukum Perdata Internasional (Suatu Orientasi). The $3^{\text {rd }}$ Print. Jakarta : Rajawali Pers. 1991.

Purwosutjipto, H.M.N. Hukum Perwasitan. Jakarta: Jembatan, 1984.

Rajagukguk, Erman. Arbitrase Dalam Putusan Pengadilan. Jakarta : Chandra Pratama, 2000.

Sammartano, Mauro Rubino. International Arbitration Law. Boston : Kluwer Law and Taxation Publisher, 1990.

Soebagjo, Felix O. Arbitrase di Indonesia. Jakarta : Galia Indonesia, 1995.

Sumampouw, Mathilde. Pilihan Hukum Sebagai Titik Pertalian Dalam Hukum Perjanjian Internasional. Jakarta: Doctoral Disertation of FHUI, 1958.

Suparman, Eman. Pilihan Forum Arbitrase Dalam Sengketa Komersial Untuk Penegakan Keadilan. Jakarta: Tatanusa, 2004.

Suwardi, Sri Setianingsih. Penyelesaian Sengketa Internasional. Jakarta: UI Press, 2006.

Tay Swee Kian, Chaterine. Resolving Dispute by Arbitrase. Singapore: National University of Singapore Press, 1998.

Yuhassarie, Emmy.(editor). Proceedings, Arbitrase Dan Mediasi. Jakarta: Pusat Pengkajian Hukum, 2003.

Zaini, Hasan dalam Budi Lazarusli, SH \& Syahmin A.K, SH. Suksesi Negara Dalam Hubungannya dengan Prjanjian Internasional. Bandung: Remadja Rosdakarya CV, 1986.

Zuraida, Tin. Prinsip Eksekusi Putusan Arbitrase Internasional di Indonesia, Teori dan Praktek Yang Berkembang. Surabaya: PT Wastu Lanas Grafika, 2009.

Papers or Thesis

Longdong, Tineke Tuegeh. "Pelaksanaan Konvensi New York 1958: Suatu Tinjauan atas Putusan-putusan Mahkamah Agung RI dan Pengadilan-Luar Negeri mengenai 
ketertiban umum". Disertation of University of Indonesia, Jakarta 1997.

Mathilde, Sumampouw. Pilihan Hukum Sebagai Titik Pertalian Dalam Hukum Perjanjian Internasional. Jakarta: Doctoral Disertation of FHUI, 1958.

Suparman, Eman. Pilihan Forum Arbitrase Dalam Sengketa Komersial Untuk Penegakan Keadilan. Disertation of Diponegoro University, Semarang 2004.

Wibowo, Basuki Rekso. "Arbitrase Sebagai Alternatif Penyelesaian Sengketa Perdagangan di Indonesia". Disertation of Airlangga University, Surabaya 2007.

Zuraida Tin, "Prinsip Eksekusi Putusan Arbitrase Internasional di Indonesia, Teori dan Praktek Yang Berkembang". Disertation of Airlangga University, Surabaya 2006.

Articles

Abdurrasyid, Priyatna. "Pengusaha Indonesia Perlu Meningkatkan Minatnya terhadap Arbitrase Dan Alternatif Penyelesaian Sengketa", in the Business Legal Journal, Vol. 21, October-November 2002, page 11.

Adolf, Huala. "Improving the Enforcement of International Arbitration Awards In ASEAN Countries". Worksheet on ALSA 10th General Assembly 2009, HanoiVietnam, 14-18 October 2009.

Arfazadeh, Homayoon."Shadow of The Unruly Horse: International Arbitration And the Public Policy Exception". American Review International Arbitration. 43(2001):63-64.

Bond, Stephen R. "How to draft an ICC Arbitration Clause (Revisited)", ICSID Review Foreign Investment Law Journal, (1992) : 155.

Boy. "Pertamina Menang di Singapura". Kompas, 26 August 2005.

Buchanan, Mark A. "Public Policy and International Commercial Arbitration". American Law Journal 26(1988):512.

Collins Q.C., Michael. "Privacy and Confidenciality in Arbitration Proceedings", Texas International Law Journal, Vol. 30 (1995):126.

Craig, W Laurence. "Some Trends and Developments in The Law and Practice of International Commercial Arbitration". 30 Texas International Law Journal, vol.I: 11.

Drahozal, Christoper R. "Enforcing Vocated International Arbitration Awards: An Economic Approach, 11 American Review International Arbitration (2000):451-455.

Evans, Heather R. “ The Non Arbitability of Subject Matter Defense to Enforcement at Foreign Arbitral Awards in United States Federal Court", International Law and Politics, Vol. 21 (1989): 330

Giambastian, Chaterine A. "Recent Development : Lex Loci Arbitri and Annulment of Foreign Arbitral Awards in U.S. Court." American University International Review (2005).

Hasan, Agus Salim. "Menyoal Kepastian Hukum Arbitrase”, (Magazine GATRA 14 February 2007), page 30.

Harahap, M. Yahya. "Sinopsis Problematik Ekekusi Di Indonesia”. A Paper presented in the Interactive Discussion organized by Hukum Online in Jakarta, 31 March 2010.

Hwary, Michael. " Enforcement of Arbitral Awards in Singapore." International Arbitration Review 3, 2000: 211-212.

Juwana, Hikmahanto. " Pembatalan Putusan Arbitrase Internasional oleh Pengadilan Nasional”, Jurnal Hukum Bisnis, vol.21 (October-November 2002): 68-69.

"Lokakarya Terbatas tentang Arbitrase dan Mediasi Jakarta, October 2002", in the PPH Newsletter Kajian Hukum Ekonomi dan Bisnis No. 52, March 2003.

"Problematika Eksekusi Putusan Arbitrase Asing Di Indonesia". A Paper 
presented in the Interactive Discussion organized by Hukum Online in Jakarta, 31 March 2010.

Kusumah Atmadja,Z. Asikin. "Arbitrase Perdagangan Internasional”, PRISMA, Year II No. 6/1973, Jakarta 5 November 1973, page 54.

"Kasus Karaha Bodas, Kejaksaan Beri Petunjuk Kepada Penyidik". Hukum Online, 5 November 2004.

Leo."Presiden Diminta Tuntaskan Pengusutan Dugaan Korupsi Karaha Bodas". 5 November 2004.

Longdong, Tineke Tuegeh. "Putusan Arbitrase Asing Dapat Dibatalkan Di Indonesia". Magazine Hukum dan Pembangunan, Vol.XXXIII No.2 January-March 2003: 246-256.

Mills, Karen. "Enforcement of Arbitral Awards in Indonesia Issues Relating to Arbitration and The Judiciary". A Paper in the Business law Journal Vol. 21, October-November 2002: 55.

"Arbitration in Indonesia. The Chapter on Indonesian from Arbitration in Asia". A Paper in the Proceedings of Pusat Pengkajian Hukum: 96 - 128. Jakarta: Pusat Pengkajian Hukum, 2004.

Oehmke, Thomas H. "Arbitrating International Claims-At Home and Abroad".81 American Jurisprudence Trials, 1 May 2007:269.,

Panggabean, H.P. "Efektivitas Eksekusi Putusan Arbitrase Dalam Sistem Hukum Indonesia", in the Business Law Journal (Vol. 21, October-November 2002), page 75.

Pinto, M.C.W. "Structure, Process, Outcome: Thoughts on the "Essence" of International Arbitration", Leiden Journal of International Law, Vol. 6, No.2 (August, 1993): page 243.

Rajagukguk, Erman. "Keputusan Arbitrase Asing Mulai Dapat Dilaksanakan Di Indonesia". Suara Pembaruan, 7 June 1990, page II.

" Implementation of the 1958 New York Convention in Several Asian Countries: The Refusal of Foreign Arbitral Awards Enforcement on The Grounds of Public Policy." (A Paper presented in the The 3rd Asian Law Institute (ASLI), Shanghai, 25-26 May 2006).

Simanjuntak, Ricardo. "Konflik Yurisdiksi Antara Arbitrase Dan Pengadilan Negeri", in the Business Law Journal (Vol. 21, October-November 2002), page 85.

$\mathrm{Su}$, Jessica L. "Enforcement of Arbitral Awards: A survey of Selected Asia Jurisdiction." International Arbitration Law Review 3, 2000: 180.

"Peluang Novum Kasus Karaha Bodas Tergantung Hukum Acara Di America Serikat". Hukum online, 28 January 2004.

"Putusan Arbitrase Internasional Digugat Pembatalannya". Varia Peradilan No.233 Year 2004, page $4-27$.

"Arbitration In Singapore: The Establishment of Legal Framework to Support International Arbitration." World Arbitration \& Mediation Report 10. October 1999, 258.

Umar, M. Husseyn. "Pokok-Pokok Permasalahan Tentang Pelaksanaan Putusan Arbitrase Internasional Di Indonesia”. A Paper presented in the Interactive Discussion organized by Hukum Online in Jakarta, 31 March 2010.

Ungar Keneth T. "The Enforcement of Arbitral Awards Under UNCITRAL's Model Law of International Commercial Arbitration." Columbia Journal of Transnational Law 25, 1987: 726.

\section{Regulations}

Indonesia. Decree of the President of the Republic of Indonesia on Legalization of the 1958 New York convention. Keppres No.34, Statetue Book No.40 Year 1981. 
. Law on Arbitration and Alternative Dispute Settlement. Law No. 30, Statetue Book No.138 Year 1999.

------. Law No. 40 Year 2007 on Limited Liability Companies).

------. Decree of the President of the Republic of Indonesia on Defferment/Review of the Government, BUMN And Private Projects That Related to the Government nad BUMN. Keppres No. 39 Year 1997.

-----. Decree of the President of the Republic of Indonesia No. 5 Year 1998.

Supreme Court of the Republic of Indonesia. Regulation of the Supreme Court of the Republic of Indonesia on Procedures for Foreign Arbitral Award Enforcement in Indonesia. Regulation of the Supreme Court RI No. 1 Year 1990.

Geneva Convention on The Execution of Foreign Arbitral Awards of 1927.

New York Convention on The Recognition and Enforcement of Foreign Arbitral Awards of 1958.

United Nation Commission on International Trade Law. Model Law on International Commercial Arbitration.

\section{Legal Documents}

Award No. 113/1980 G, North Jakarta District Court dated 18 Desember 1980.

Award No. 57/1981/PT/Perdata, Jakarta High Court dated 7 May 1981.

Award No. 499/Pdt/G/VI/1988, Central Jakarta District Court.

Award No. 486/Pdt/1989/PT.DKI, Jakarta High Court dated 14 October 1989.

Provisional Judgment No. 46/Pdt.G/1999/PN. Jaksel, South Jakarta District Court, 3 May 1999.

Stipulation No. 04/Pdt/Arb.Int/1999/PN.JKT.PST, Central Jakarta District Court, 3 February 2000.

Award No. 86/PDT-G/2002/PN.JKT-PST, Central Jakarta District Court dated 19 August 2002.

Award No. 01/Pembatalan Arbitrase/2009/PN.JKT.PST, dated 31 August 2009.

Stipulation of Central Jakarta District Court, on refusal of enforcement of international arbitral awards from the SIAC, 28 October 2009.

Award No. 01/Pembatalan Arb/2009/PN. JKT.PST, Central Jakarta District Court, 3 September 2009.

Award No. 2924/K/Sip/1981, Supreme Court of the Republic of Indonesia dated 8 February 1982.

Award No. 4231K/PDT/1986, Supreme Court of the Republic of Indonesia.

Supreme Court of the Republic of Indonesia No. 1203K/Pdt/1990 jo. Perdata No. 736/ Pdt/G/VI/1988/PN.JKT.PST jo.PT Jkt No. 485/Pdt/1989/PT DKI

Supreme Court of the Republic of Indonesia No. 01 K/Ex'r/Arb.Int/Pdt/2000, 5 September 2000.

Supreme Court of the Republic of Indonesia No. 1/BANDING/WASIT-INT/2002, dated 8 March 2004.

Supreme Court of the Republic of Indonesia No. 01 K/Pdt. Sus/2010, 24 February 2010.

Supreme Court of the Republic of Indonesia No. 64 K/PDT.SUS/2010, 26 April 2010.

Supreme Court of the Republic of Indonesia No. 904 K/PDT.SUS/2009, 9 June 2010. 